\title{
A Case for Dehahuit's Village Part I
}

Jim Tiller

Unknown

Follow this and additional works at: https://scholarworks.sfasu.edu/ita

Part of the American Material Culture Commons, Archaeological Anthropology Commons, Environmental Studies Commons, Other American Studies Commons, Other Arts and Humanities Commons, Other History of Art, Architecture, and Archaeology Commons, and the United States History Commons

Tell us how this article helped you.

This Article is brought to you for free and open access by the Center for Regional Heritage Research at SFA ScholarWorks. It has been accepted for inclusion in Index of Texas Archaeology: Open Access Gray Literature from the Lone Star State by an authorized editor of SFA ScholarWorks. For more information, please contact cdsscholarworks@sfasu.edu. 


\section{A Case for Dehahuit's Village Part I}

Creative Commons License

(c) (i) (2)

This work is licensed under a Creative Commons Attribution-NonCommercial 4.0 International License 


\section{A CASE FOR DEHAHUIT'S VILLAGE PART I ${ }^{1}$}

\section{Jim Tiller}

\section{Introduction}

During the late 1700s, the Kadohadacho (hereafter Caddo), a peaceful tribe of agriculturists and hunters, weakened by near-constant pressure from the more war-like Osage and the ravages of various epidemics, began to migrate from their traditional homeland near the Great Bend of the Red River south into northwestern Louisiana and adjacent East Texas. By the time of the Louisiana Purchase in 1803, the Caddo villages under their caddi Dehahuit were concentrated in the Sodo Lakes region west and northwest of modern-day Shreveport. Much of what we know today about the location of these settlements, and specifically Dehahuit's village, are found in the writings of Indian agents and the field notes and plat maps of period surveyors. In this article we will examine these and other relevant documents and present a case for the location of the village of this historic figure.

It is the contention of the author, based on material to be presented in the pages to follow, that Dehahuit's village will ultimately be found to lie northwest of Waskom, Texas on the southern terraces of Paw Paw Bayou beneath the neatly manicured lawns of the Victoria Wood subdivision. The site is depicted on the 1838 American surveys of northwestern Louisiana as lying on the Natchitoches-to-Pecan Point Road on the section line between Sections 2 and 3 of T17N, R17W. In support of this argument, we will examine in this article (1) a relatively definitive 1840 statement regarding the location of Dehahuit's village by Jehiel Brooks, long-time Caddo Agent and the individual who engineered the sale of the Caddo lands to the United States; (2) the well-known 1805 statement of Red River Agent John Sibley in which he noted that the Caddo lived some 35 miles west of the Red River on a bayou "called, by them, Sodo;" and (3) a memorial statement by the Caddo themselves regarding the re-location of some of their villages as required by Article 4 of the 1835 treaty cession.

\section{Known Caddo Village Sites}

Much of the literature of the last 25 years has implied that most, if not all, of the late 1700 -early $1800 \mathrm{~s}$ Caddo settlements were located north of Caddo Lake. In recent years, writers have typically suggested that the Caddo occupied but a single village located just inside Texas on Jim's Bayou. ${ }^{2}$ In fact, by the early 1800s, the Caddo may have occupied as many as 30 settlements within the Red River region. ${ }^{3}$ Although the location of most of these sites is lost to history, the great majority of those currently known, including the village of Dehahuit, are located south of the Sodo Lakes complex.

The archival record indicates that at one time or another at least 14 late 1700 -early 1800 s settlements were occupied by elements of the Caddo tribe in the Sodo Lakes region (Figure 1). ${ }^{4}$ In addition to the Jim's Bayou site, ${ }^{5}$ the North Caddo, ${ }^{6}$ Middle Caddo, ${ }^{7}$ Big Spring Caddo, ${ }^{8}$ Dehahuit's, ${ }^{9}$ Caddo Prairie Floodplain, ${ }^{10}$ Cedar Bluff, ${ }^{11}$ Peach Orchard Bluff, ${ }^{12}$ Agent Sewall's Caddo $^{13}$ and Col. Many's Caddo ${ }^{14}$ villages are either actually named in period materials or their presence can be inferred from the historical record as one-time Caddo settlements. While not designated by name in period documents, the Border ${ }^{15}$ and Louisiana ${ }^{16}$ villages 
are almost surely Caddo. The Small village ${ }^{17}$ site mentioned in a Republic of Texas survey is very likely Caddo. A Mexican survey sketch map of the Mooringsport "village"18 is drawn in such a manner as to make it difficult to determine whether what is depicted in the middle of a substantial prairie is an Indian settlement (maybe) or a pine hill (probably).

While there were doubtless a great number of small temporary encampments and possibly even some additional yet-to-be-located permanent settlements that may have been Caddo, the presently known sites probably represent the more prominent Caddo villages in the region in the late 1820s and 1830s. It should be noted that both American and Republic of Texas surveyors were active across the area during the late 1830s and early 1840s. The American surveyors carefully catalogued period roads, trails, paths, Indian villages and Anglo improvements (and even the path of a tornado) as they made their way, mile by mile, across individual townships. ${ }^{19}$ Early Texas surveyors, especially those marking out first and second class headright land in early 1838, while including many of the same items on their survey sketch maps, often used nearby Indian villages as landmarks in the general reference section of their field notes. As a result of their survey work, it is doubtful any substantial village escaped notice.

By far the most historically significant Caddo settlement in the region was the village of the great caddi, Dehahuit. This was the village referred to in the journals of the Freeman and Custis expedition, ${ }^{20}$ and it was in this village that Spanish soldiers cut down an American flag in 1806 causing a minor diplomatic incident. ${ }^{21}$ Since we know Dehahuit lived in the same village from the early 1800 s up to the date of his death in $1833,{ }^{22}$ it is a virtual certainty that one of the known sites is associated with this individual.

\section{Jehiel Brooks' 1840 Comment on the Location of Dehahuit's Village}

On January 30,1840, Jehiel Brooks answered the memorial of Samuel Norris in the matter of the Grappe land claim. ${ }^{23}$ Within this filing, Brooks, who devoted an entire paragraph to defining the location of the village of Dehahuit, noted that

The Indian south boundary as expressed in the treaty made by your respondent he believes cannot be questioned with any greater propriety. The Head Chief of the Caddo nation named Dehahuit or Dehahut resided at what has always been known by the name of "the Key Village" from the time of the first council ever held by this Government with that functionary in May 1805 to the time of his death in March 1833 which village is situated within a short distance of said Boundary and about ninety miles from the town of Natchitoches. ${ }^{24}$

This statement, by an individual who travelled extensively within the Caddo nation and who doubtless knew Dehahuit well, is the single most authoritative statement available on the matter of the location of Dehahuit's village. When combined with other more circumstantial evidence, Brooks' comment leaves little doubt that this site was located west of Cross Lake on Paw Paw Bayou (see Figure 1).

Brooks indicated Dehahuit's village was situated near the south boundary of the Caddo lands conveyed to the United States. We know that the southern treaty boundary extended from the Red River to the Mexican line via Pascagoula Bayou, Bayou Pierre, Bayou Wallace, Wallace Lake and Cypress Bayou. ${ }^{25}$ American surveyors found only one Indian settlement in the immediate vicinity of the Caddo south boundary - the Louisiana village. ${ }^{26}$ 


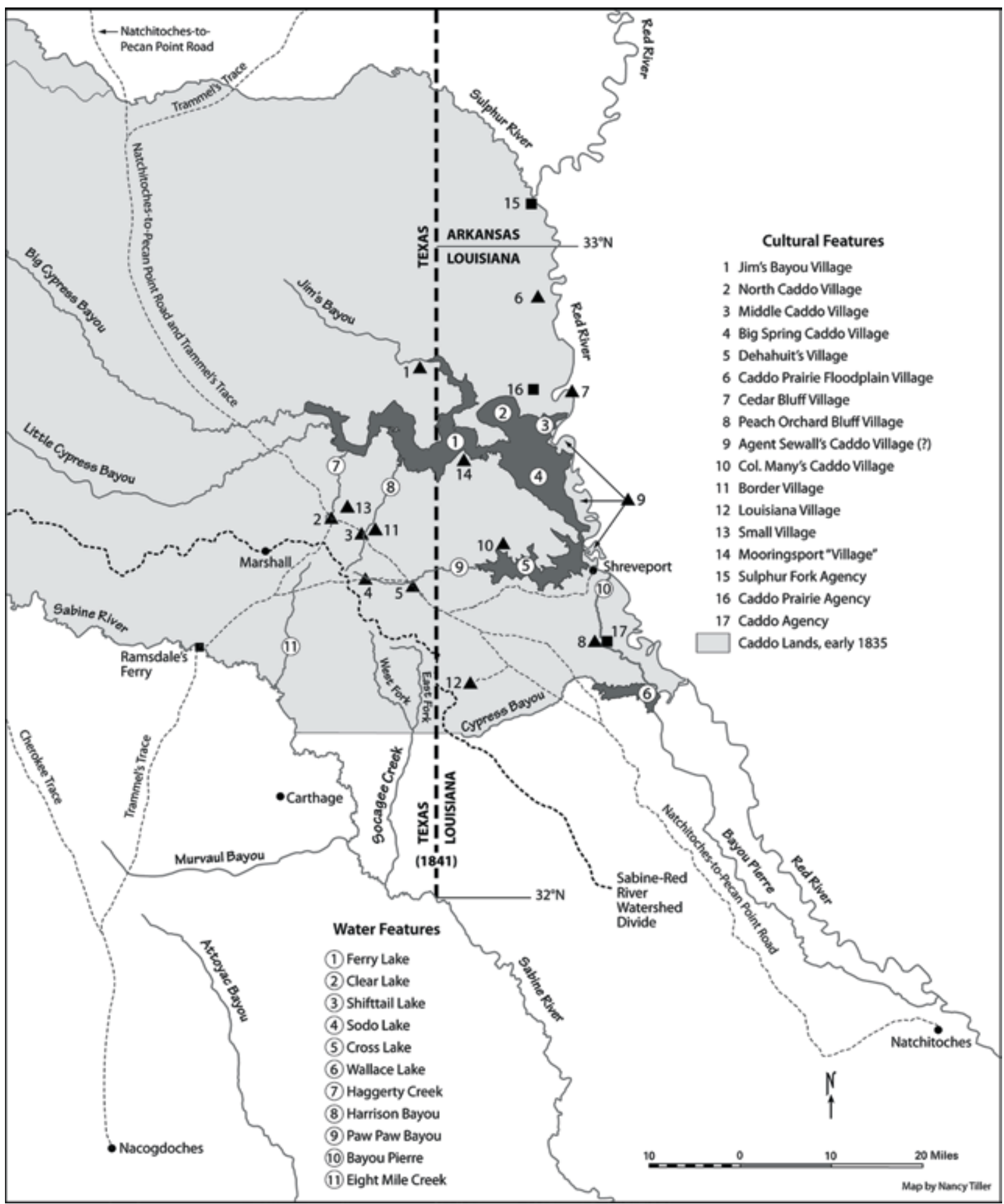

Figure 1. ${ }^{60}$ Late 1700 s-Early 1800s Caddo Village Sites in the Sodo Lakes Region. 
The question, of course, is what did Brooks mean when he said the "village is situated within a short distance of said Boundary?" Fortunately, he clarified the statement when he noted that the settlement was located "about ninety miles from the town of Natchitoches." The primary road running northwest out of Natchitoches into Caddo country, the Natchitoches-to-Pecan Point Road, is clearly delineated on the 18371838 American survey plat maps of northwestern Louisiana. ${ }^{27}$ The distance between Natchitoches and the Louisiana village, as depicted on these maps, is approximately 75 miles. While it might be tempting, based on proximity to the southern Caddo boundary, to suggest that this village was the home of Dehahuit, considered in the full context of this article, the best case suggests that Brooks was in fact not referring to the Louisiana village in his statement.

Dehahuit's village on Paw Paw Bayou is approximately 87 miles from the town of Natchitoches via the old Natchitoches-to-Pecan Point Road. The definition of "within a short distance" can be debated endlessly, but the 90-mile distance referred to by Brooks is much more precise and meaningful. The only question is just how accurate was Brooks' estimate of the distance? While caution should certainly be exercised when working with period estimates of distances, in fact, such calculations are often found to be surprisingly accurate considering the means of measurement employed. Many distances described in archival materials are based on estimates of the mileage covered by horse (or an individual walking) within a given time period. During his stint as Caddo Agent, Brooks doubtless used this method frequently in his travels around the Caddo nation and to Natchitoches. Too, by the time Brooks submitted his answer to Norris' memorial in 1840, the American surveys had been completed in this section of Louisiana providing yet another corroboration of distances between known points (Figure 2). It is doubtful Brooks was far off in his estimate of 90 miles.

Brooks' statement is the centerpiece of the case for Dehahuit's village being situated on Paw Paw Bayou near the western end of Cross Lake. While some, especially those wedded to the Jim's Bayou as Timber Hill/Dehahuit's village theory, might suggest that Brooks was implying a straight-line distance from Natchitoches to the village, such a method of calculating distances frequently travelled seems highly improbable considering the means of transportation available in Brooks' time. Who among us, when asked for or stating the distance between our hometown and a nearby large city visited on occasion, would answer in straight-line miles? Time, possibly, driving mileage probably, but hardly straight-line miles. Certainly Brooks' comments, when combined with material presented in the following paragraphs, offer, pending a formal archeological effort, the single most important piece of circumstantial evidence for Dehahuit's village being northwest of present-day Waskom.

\section{The 1805 Statement of John Sibley}

In his April 1805 “Historical Sketches," Red River Agent John Sibley noted that the Caddo

Live about thirty-five miles west of the main branch of Red river, on a bayou or creek, called, by them, Sodo, which is navigable for pirogues only, within about six miles of their village, and that only in the rainy season. ${ }^{28}$

It is this quote, one that has been so misinterpreted by modern writers, that has largely given rise to the myth of the Jim's Bayou site as the home of Dehahuit. In this section, we will begin by noting the distance from the Red River of the three most probable Dehahuit village candidates. Dehahuit's village on Paw Paw Bayou lies some 24 miles west of the Red River. By comparison, the Louisiana village is situated approximately 18 miles west of the Red; the Jim's Bayou site lies some 24 miles west of the river. 


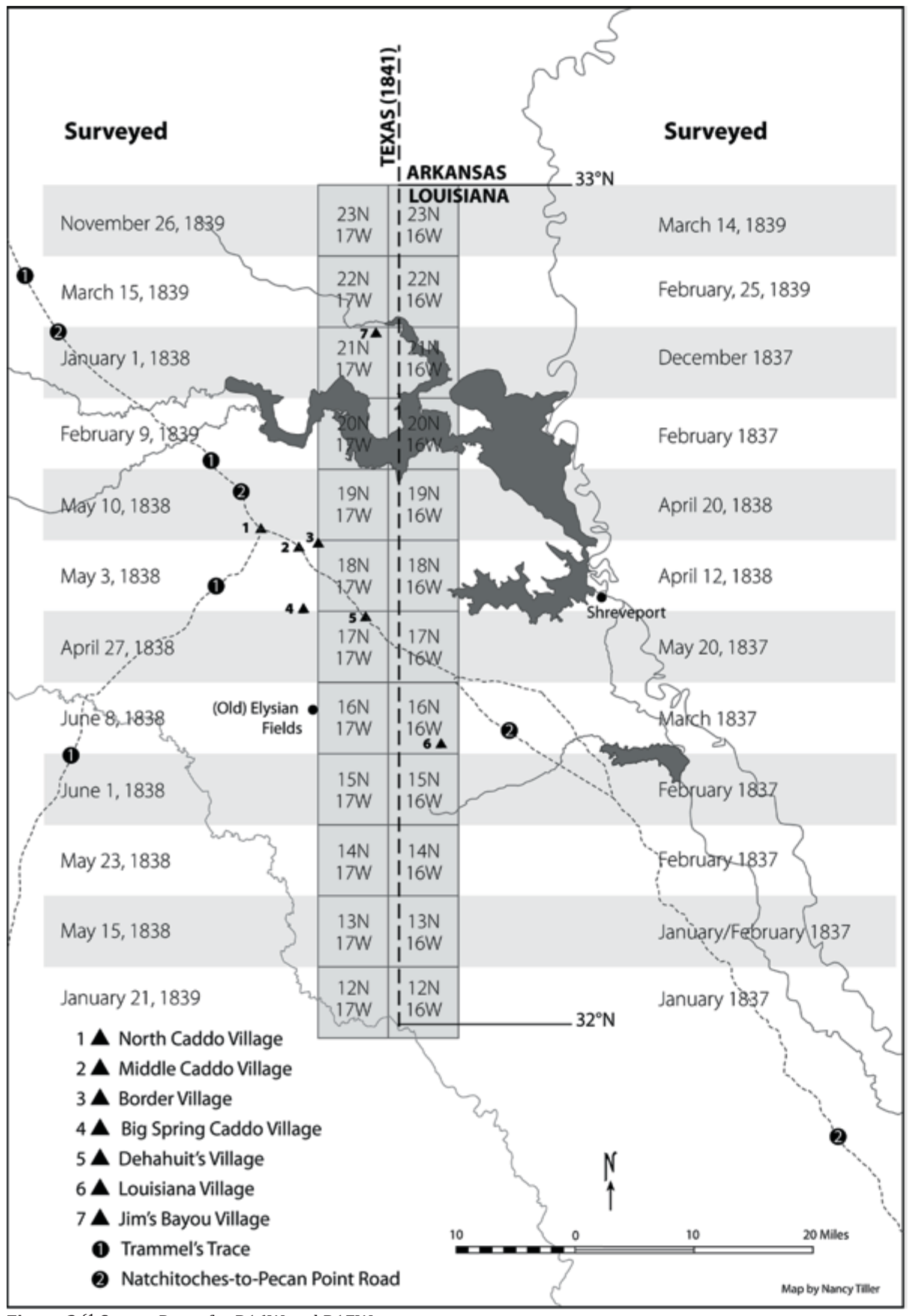

Figure $2 .{ }^{61}$ Survey Dates for R16W and R17W. 
While the distances from the Red River are significant, and could possibly cause one to give some consideration to the Jim's Bayou site, perhaps of even greater importance is Sibley's statement as regards the Caddo living on a "bayou or creek, called, by them, Sodo, which is navigable for pirogues only, within about six miles of their village, and that only in the rainy season." It appears to the author that most Caddo scholars who have addressed this topic have failed to consider the fact that the Sodo Lakes complex had been formed less than five years (spring 1800) when Sibley wrote his "Sketches." Who among us has not had the occasion to observe the process of sedimentation across open ground reduce a one or two-acre farm pond in East Texas by 10 or 15 percent within a few short decades? For ponds fed by permanent streams with their higher sediment loads, the rate of infill is considerably more rapid. As Sibley penned his words in April 1805, the sedimentation process was just getting underway along Jim's and Paw Paw Bayous. By the time the American surveyors drew their plat maps in the late 1830s, sedimentation at the upper end of the respective lakes had doubtless created significant changes from the scene Sibley described.

The average level of Ferry (Caddo) Lake in 1838 (and very likely in 1805 as well) is estimated by Bagur to have been approximately two feet higher than today's 168.5 feet maintained by the presence of a dam on Big Cypress Bayou. ${ }^{29}$ The western end of the Jim's Bayou arm of Ferry Lake depicted on the 1838 plat map (Figure 3) is located approximately one-half mile west of the 170 -foot contour which crosses Jim's Bayou at the upper end of Monterey Lake. Such a location very closely approximates Bagur's average pre-dam lake level of 170.5 feet. Note also on Figure 3, the presence of the 174-foot elevation marker on the north side of Jim's Bayou approximately three miles west of the state line - a point almost directly across the bayou from the village site. To extrapolate, the water level shown on the 1838 plat map, which as depicted is about onesixth of the way between the upper end of Monterey Lake (170 feet) and the 174-foot elevation north of the village site, is very close to the average lake level of 170.5 feet during the pre-dam period. With the 1838 plat as a guide, and assuming 30 years of sedimentation, it is more than reasonable to suggest that at the time Sibley wrote his "Historical Sketches" in 1805, Jim's Bayou and its floodplain was somewhat lower than that shown on the 1838 survey map, hence the arm of Ferry Lake depicted doubtless extended upstream (westward) a greater distance.

Note how the American surveyor illustrated the Jim's Bayou floodplain on the 1838 plat map, especially the area north of and upstream from the village site (the swampy land). The map suggests a stream valley that is being silted - as would be expected if a lake had been formed downstream in the recent past. The creation of the Sodo Lakes complex would have had the effect of further reducing the already relatively low gradient of Jim's Bayou causing the stream to deposit a portion of its load along its adjacent floodplain, and especially at the point where the bayou entered the still waters of the lake. Over time, this would have raised the height of the floodplain as well as the stream itself and caused the lake to recede downstream (in much the same manner a pond gets smaller over time).

Today, the 175-foot contour (which was almost surely under water during the rainy season prior to 30 years of silting) crosses Jim's Bayou just south of the point at which Mill Creek enters the larger stream, some 1.5 miles upstream from the Jim's Bayou village site. In all probability, as sedimentation was in its earliest stages at the beginning of the 1800s, the stream and associated valley (lying to the north of the Jim's Bayou archeological site) was filled by a substantial lake that was perhaps as much as one-half mile across. The presence of such a lake adjacent to the village would not have been compatible with the description provided by Sibley in his "Historical Sketches." 


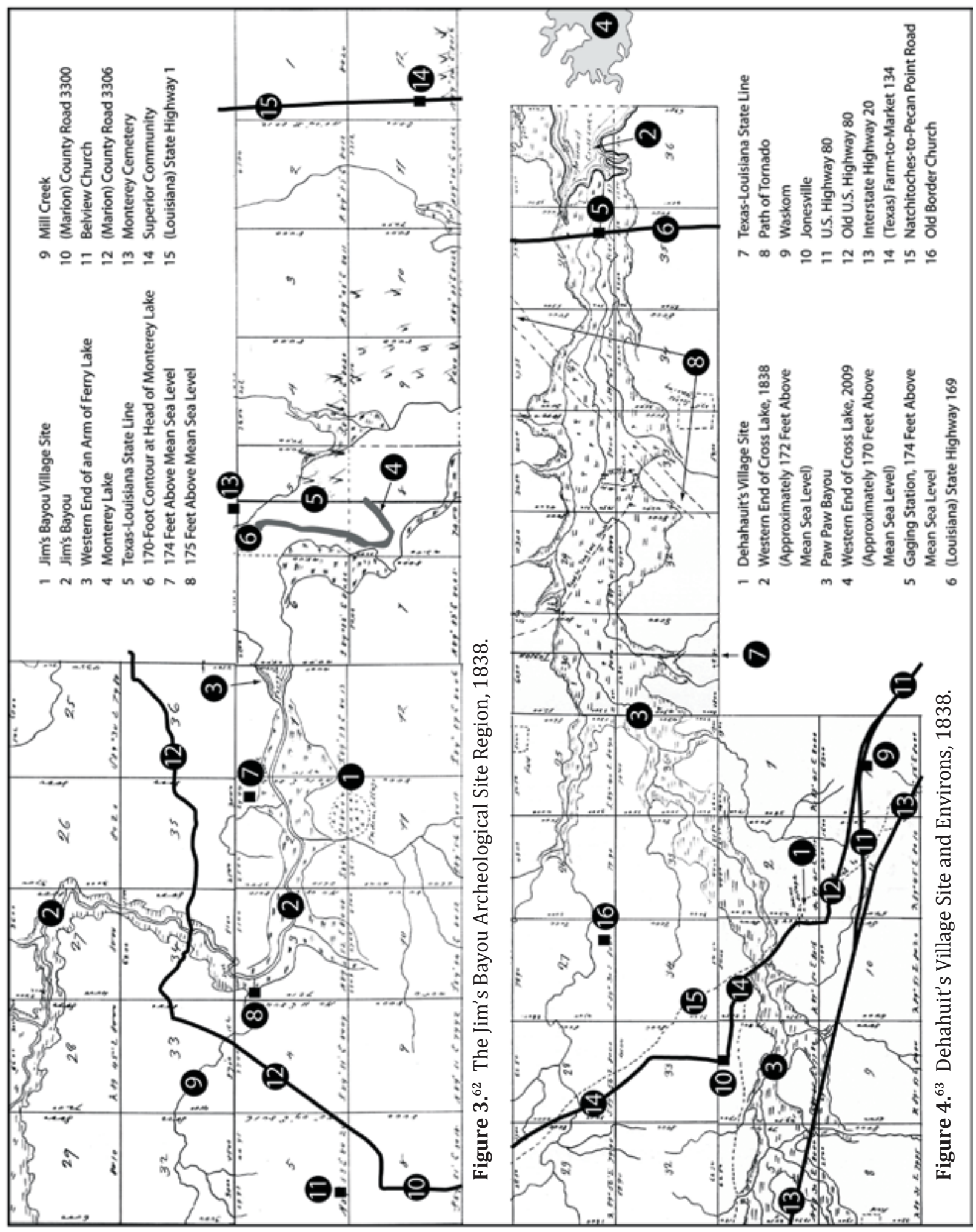


The same general conditions would have existed at the head of Cross Lake in the early 1800s. Doubtless this lake also extended upstream a greater distance than is the case today. If we assume the lake levels of both Ferry/Caddo and Cross Lakes to have averaged approximately the same height above mean sea level (170 feet), then it appears that, because of the steeper stream gradient of Paw Paw Bayou, the western shore of Cross Lake in the early 1800s was probably less than one mile west of its current location (Figure 4). Interestingly, flood stage on Cross Lake today typically approaches 175 feet above mean sea level ${ }^{30}$ - the 175foot contour being almost exactly six miles east of the Dehahuit village site.

The Louisiana village is located on the south branch of Boggy Bayou, a stream which joins Cypress Bayou just before entering Wallace Lake. The village site is more than 8 miles from the 170 -foot contour - thus placing it far to the west of any substantial lake known to have existed in the area in the early 1800s. Too, it should be noted that the pioneer northwest Louisiana Wallace family, some of whom lived on the southern shore of this lake, would have been well-known to Sibley in $1805 .{ }^{31}$ It is highly unlikely he would have so misjudged the lake upon which this family lived and its distance from the Louisiana village. If the Brooks and Sibley comments do not remove the Louisiana village from contention as the home of Dehahuit, then, as we will take up in the following section, the 1837 Caddo memorial on the matter of village re-location ought to.

In summary, in 1805 the Jim's Bayou village was probably situated on a lake - but certainly not on a creek "navigable for pirogues only, within about six miles of their village, and that only in the rainy season." By comparison, Dehahuit's village site would have been found on a creek some six miles west of the western shore of Cross Lake. On balance, Sibley's description in terms of both distance from the Red River as well as the relationship of the village to the lake via the adjacent creek certainly applies much more closely to the Paw Paw site than to either the Jim's Bayou or Louisiana villages.

\section{The January 6, 1837 Caddo Memorial to the Secretary of War on the Matter of John G. Green}

Sibley, in his "Historical Sketches," provided a name for the watercourse upon which the primary Caddo village was located - Sodo. Caddo scholars are aware that the period literature is filled with references to (and maps of) Sodo Lake - a southeast to northwest trending lake that once lay between modern-day Shreveport and Caddo Lake, parallel to and including the channel of Twelvemile Bayou (see Figure 1). Certainly it would seem reasonable to suggest that Sibley's Sodo Bayou must have fed into this lake. Since the primary watercourse entering old Sodo Lake was Big Cypress Bayou, it would be logical to assume Dehahuit's village, once located, would be found to lie within the Big Cypress watershed. With the discovery of the Jim's Bayou site, it was a short leap to associate this village with the great caddi Dehahuit.

Based upon the totality of the material presented within this article, it seems clear that such an assumption was in error. We know from Brooks that Dehahuit probably lived near the western end of Cross Lake from at least as early as 1805 until his death in 1833. Sibley's description of the relationship between the stream upon which the Caddo village was located and a nearby lake almost surely removes the Jim Bayou site from contention as the settlement described. Was Sibley wrong in noting that the primary Caddo village was located on a creek by the name of Sodo, or could it be that later writers, at least according to Caddo tradition, have re-named one of the lakes? It appears from the record that the lakes identified as Sodo by the Americans and the Caddo were not one in the same. 
Except for Sibley's comment noting that the Caddo lived "on a bayou or creek, called, by them, Sodo" [author's emphasis], there is only one other instance that the author is aware of where the Caddo themselves make reference to a water body called Sodo. In a January 9, 1837 memorial to the Secretary of War, the chiefs and head men of the Caddo nation protested the naming of any individual to serve as their attorney-in-fact, or to act for them, in the matter of their 1837 annuity other than John G. Green. Near the bottom of the memorial is found the following paragraph, apparently inserted by the Caddo to note their compliance with the 1835 treaty article that required them to remove from the bounds of the United States within one year.

We have established our villages near the head of Lake Sodo, which we believe to be without the boundary of the United States, but on running the line between Mexico and the United States, should it be found to be within the jurisdiction of the latter, we will instantly remove further to the West. Hope you will inform the president of our great wish, to have this line run out, as we can make no permanent settlement until this is done. ${ }^{32}$

In the following paragraphs we will discuss this passage in terms of three items: (1) What did the Caddo believe their western boundary to be; (2) Is there any evidence of "new" Caddo villages near the head of Lake Sodo; (3) What did the Caddo mean by Lake Sodo?

\section{Larkin Edwards}

To begin, the interpreter for this 1837 memorial was Larkin Edwards, Sr. This individual was wellknown to the Caddo; they having dealt with him many, many years prior to the date of the memorial. The Caddo undoubtedly had the highest respect for Edwards, and apparently had always found him an honest man - and one who worked in their best interests. So great were their feelings for Edwards that they gave him a 640-acre reservation in the 1835 treaty to be located at a place of his choosing within the confines of their lands ceded to the United States (he chose a site that later became Shreveport). ${ }^{33}$ It seems entirely reasonable to assume that such a relationship would have resulted in a highly accurate, and possibly even a word for word, translation of the wishes of the Caddo.

\section{The Caddo View of the Western Boundary of their Cession}

The memorial tells us that the Caddo had recently moved their villages westward from areas they believed to have been within the bounds of Louisiana. The question is, what did they believe to be the western boundary of their cession to the United States? The answer can be found in several depositions taken in the matter of the Grappe claim. A number of individuals testified to the fact that the Caddo believed their boundary to have been Terán's Line. Consider

Sylvestre Poissoit, who swore that the Caddo told him

... that the country sold by them to Mr. Brooks was bounded by the line made by General Terán, and lay from where that line struck the "first red water" 34 to Cyprus bayou, and thence west ... ${ }^{35}$

Joseph Valentin, who stated

that the Indians told him they had sold from the river Sabine along Terán's line to where it intercepts the first red water, and thence up. ${ }^{36}$ 
Manuel Laffitte, who testified that

The Indians have told him what lands they sold by treaty in 1835, but not the quantity; they sold from Terán's line, where it touched Red river, out towards sunset. ${ }^{37}$

While it is not possible to precisely establish the point at which Terán's Line passed through the region, its approximate location can be readily calculated from Aldrich's Surveys between the Sabine and Red Rivers made for titles under Radford Berry, Commissioner. ${ }^{38}$ Based on this map and comments by Brooks which follow, it appears that Terán's Line passed through the last tier of sections in R15W (Figure 5) ${ }^{39}$ Such a placement is confirmed by Brooks' summation to the jury in his District Court trial (Brooks vs Norris) in which he observed that in the fall of 1828 he met General Mier y Terán near the head of Cross Lake and was informed by him that he was in the area to informally establish the line between Mexico and the United States. Based on information Brooks later acquired from the Caddo regarding Terán's Line, he determined that the line

... passed close to the head of Cross Lake, leaving all the Indian villages on the Texas side of it ... [Brooks also observed that] it was generally known that his [Terán's] line was too far east of a due north course from Darby's corner as it was called to be thought correct. $^{40}$

Interestingly, Brooks also noted in his summation that a meeting

took place some sixteen miles west of Shreveport, which cannot be far from the Texas line: Terán's must have been near to, or a little east of Smyth's ... ${ }^{41}$

The meeting referred to was held in September 1837 at the home of Col. John Smith who lived south of Cross Lake and whose improvement was duly noted by the American surveyors. As a result of this meeting, the Caddo sent a memorial to the Senate of the United States stating that in the treaty of cession they had not reserved any land for the Grappes, and that Brooks had in effect committed a fraud upon the American government. ${ }^{42}$

Finally, Brooks observed in his summation that

Cesair Laffitte testified that the Indians called himself and others to attend at Smyth's, in order to inform the Government that they had never made any reservations to the Grappes; and that having once been deceived by Brooks, they did not wish to be again. The meaning of this would be an enigma - a downright puzzle, were it not for their having lost their villages west of the Terán line. ${ }^{43}$

It is important to keep in mind that by September 1837, the Americans had surveyed out all of R16W south of modern-day Caddo Lake (see Figure 2 for survey dates). This had resulted in the Caddo losing the Louisiana village. ${ }^{44}$ The Caddo were also doubtless aware at the time, as certainly the area settlers would have been, that the United States government had let contracts in April 1837 to survey R17W. ${ }^{45}$ Since two of their villages, one on Jim's Bayou and Dehahuit's village, were within two miles of the western boundary of R16W, there could be no question that once the surveying of R17W began, these two villages would be lost as well. 


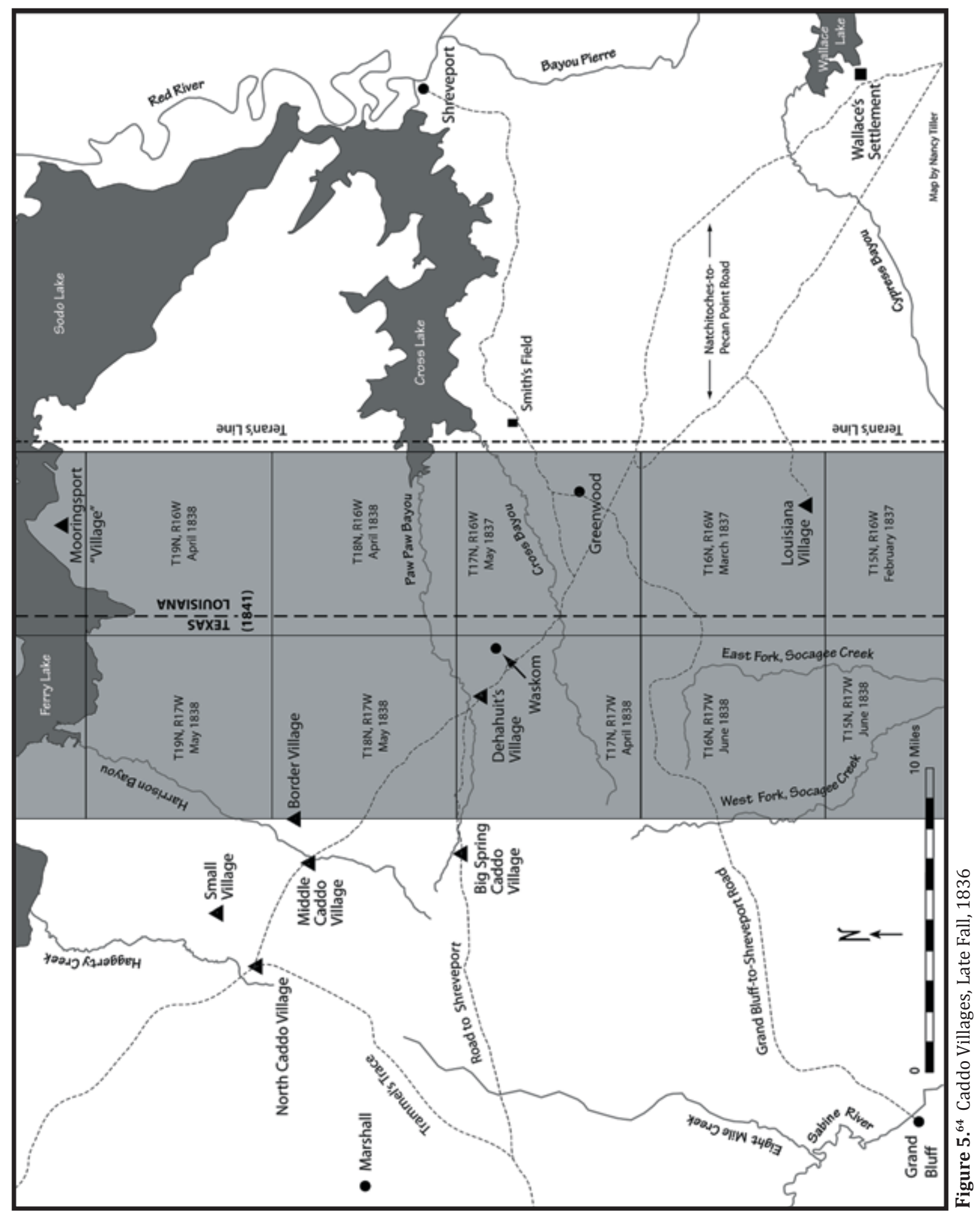




\section{Area Caddo Villages}

From the text of the January 1837 memorial, it is clear that by the end of 1836 the Caddo had removed all of their villages from points east of Terán's Line and established one or more of what they considered to be temporary villages (until the final line could be run) to the west of that line near the head of Lake Sodo. While the Caddo were obligated by the 1835 treaty to leave the United States within one year, ${ }^{46}$ they were not permitted to do so by American General Edmund P. Gaines due to difficulties in Texas associated with the Revolution. ${ }^{47}$ It is likely this permission was granted once conditions had stabilized, and after the general had sent Major B. Riley into the Caddo villages for a report on activities there. Riley's August 21, 1836 report found the Caddo

... very peaceably disposed, and it is my opinion that they never were otherwise; and if they have committed some small depredations on the inhabitants, or their property, it was occasioned by the too free use of whiskey, which appears to be in great abundance in and about their villages. ${ }^{48}$

The archival record does not reveal the precise date any of the known Caddo villages were established, however, the reader will note on Figure 1 that there are no Caddo villages near the head of Lake Sodo (as defined by the Americans) save possibly for the Mooringsport "village" - and there is nothing in the record to suggest a date for this "settlement," if it is even a village. In fact, there is no evidence that the author is aware of that suggests there was ever an Indian village in this area during the late 1700s-early 1800s period.

On the other hand, the record does suggest that the Big Spring Caddo village, lying some six miles west of Dehahuit's settlement, may have been established sometime during the fall of 1836. In April 1835, George Aldrich surveyed a number of parcels of land in the area of the village for Santos de Azco. No mention is made in these surveys of any Indian settlement, or of any human activity for that matter. ${ }^{49}$ Nor does it appear that the village was in existence in August 1836 when Major B. Riley visited four area Caddo villages. In his report prepared for General Gaines, he noted that

The country is beautiful; and if there were springs, it would be one of the best parts of the country I have travelled through. They have to use bayou water for all purposes. ${ }^{50}$

The Big Spring village was likely given its name by early Anglo settlers who were impressed with the presence of large springs in the area (several are still to be found even today). Major Riley visited four Caddo villages, probably the Louisiana, Dehahuit's, the Middle and North (or possibly the Border) villages. It seems doubtful that he would have made the statement above had he visited the Big Spring site. We know the village was occupied on February 22, 1838, when John S. "Rip" Ford surveyed what later became known the "Big Spring Caddo" tract for James Smith, assignee of Francisco Valmore. ${ }^{51}$ Ford noted that the survey included the "Big Spring Village." Later references typically included Caddo in the name. ${ }^{52}$

Finally, let us consider the naming pattern of the string of known Caddo sites stretching from Trammel's Trace to Dehahuit's village. Prior to early 1835, probably due to its isolation and the activities of the Indian agents who attempted to keep settlers off Caddo lands, eastern Harrison County contained few whites. By 1836, the battle of San Jacinto, the creation of the new Republic of Texas, the clearing of the Great Raft to a point near Shreveport, and the sale of the Caddo lands to the United States, all combined to create conditions more favorable for settlement. ${ }^{53}$ That said, even by early 1837 the region south of Caddo Lake and east of Trammel's Trace probably contained fewer than 100 families. ${ }^{54}$

\section{Volume 20, 2010}


As immigrants began to trickle into the area, they encountered the Caddo. The early contacts appear to have been generally peaceful. In an early March 1837 petition from the region, there is not the slightest hint of an Indian problem, although the Caddo were certainly still occupying villages in eastern Harrison County. ${ }^{55}$ In going about their day-to-day lives, it is likely these early Anglo immigrants assigned names to the various Caddo villages. In fact, these were probably the very names noted by Republic of Texas surveyors in early 1838. The names given to these settlements probably even suggest the relative position of Caddo sites in the area. Hence the named North Caddo village, near the intersection of the Natchitoches-to-Pecan Point Road and Trammel's Trace, was likely the northern-most settlement in eastern Harrison County. ${ }^{56}$ As pointed out in Note 7, to the south of this village on the Natchitoches-to-Pecan Point Road lay the named Middle Caddo village.

While it is the belief of the author that early 1835-1836 settlers in the region knew Dehahuit's village as the South Caddo village, no supporting evidence for such a supposition can be offered.$^{57}$ Surely, considering the presence of both a named North and Middle Caddo village, a settlement known as the South village once existed. (see email comments) Considering the location and long history of Dehahuit's village, it seems reasonable to suggest that this site is the missing southern settlement. Had it not been apparent in early 1838 that the American surveys of R17W would incorporate the village, it is very likely Texas surveyors would have noted the presence of a South Caddo village in the general reference section of their surveys in the area. That said, the name South Caddo village is not found in any archival record that the author is aware of. Although it is possible that the name may have appeared in an early deed or court filing, unfortunately the Shelby County courthouse burned in 1882 with the loss of all records (Harrison County was created from Shelby County in 1839).

As noted previously, the Big Spring Caddo village was probably created as a new settlement soon after General Gaines received Major Riley's report and gave his permission for the Caddo to begin their westward migration out of the United States. The fact this village had a non-directional period name strongly suggests that it was established at some point after initial Anglo settlement. It is not likely this new site would have taken the name South Caddo village since that name was probably already well established in the vernacular of the settlers.

The strength of the memorial paragraph lies in the fact that it was developed by the Caddo themselves and interpreted, presumably as they stated it, by an individual well-known, highly respected and trusted by them. In addition to suggesting a reason why there is no named South Caddo village, the memorial paragraph also provides a basis for establishing the age of the Big Spring village. Considering the proximity of the Big Spring village to the western boundary of R17W, it is very possible that this settlement was the location from which the Caddo came to Shreveport in the fall of 1838 never more to return to their homes in Texas.

\section{Lake Sodo}

Finally, what to make of period references to Lake Sodo? The 1837 memorial, combined with other material presented in this article, seems to suggest that the waterbodies known to the Caddo and Whites in the early 1800s as Sodo Creek/Bayou and Lake Sodo were not one in the same. It appears that Caddo references (Sibley's 1805 "Historical Sketches" comment and the 1837 memorial) to these entities were to what we know today as Paw Paw Bayou and Cross Lake. To the author's knowledge there is not a single post-Louisiana Purchase, non-Indian reference to a Sodo Creek/Bayou. White references to Sodo Lake are associated with the large lake lying northwest of Shreveport and running more or less parallel with the Red River, although the entire Sodo Lake-Ferry (Caddo) Lake complex at various times has been referred to as 
Sodo Lake. White settlers appear to have called modern Cross Lake, Coss or Cass Lake, and the major stream entering its western end as Paw Paw Bayou (early references suggest the name of the bayou was Quapaw or Village Creek).

When the name Sodo was first applied to the lake northwest of Shreveport remains a mystery. The first American reference to Sodo Lake that the author is aware of is found in the May 1826 report of Captain George Birch to General Gaines. Birch had led an expedition up the Red River with the purpose of determining a possible route through the Great Raft. He indicated that he left the Red River and made his way to Coss Lake via Coss Bayou, and then moved north into what he called Lake Sheodo. The names of Coss (later Cass and ultimately Cross) and Sheodo (Sodo) Lakes were doubtless provided to Birch by his guide, a "Mr. Wallace, who has lived 50 years in the neighborhood." ${ }^{\prime 58}$ According to a 1840 deposition, Thomas Wallace, 57 years old at the time, had "... lived in the neighborhood of Rush island [the area between the old channel of the Red River and Bayou Pierre], or in Natchitoches parish, about forty years - about thirty-five years of the time, near Rush island ..." In this same deposition, Wallace stated that the Caddo "made their first settlement in this part of the country about four years before the [1803] treaty with France, by which Louisiana was acquired ... "59 If we assume Wallace provided Birch with the names for these water bodies as known to him, and that Sibley was correct that the Caddo called the bayou upon which they lived, Sodo (and that it was to the area west of this lake that the Caddo moved their villages in the fall of 1836), then the name applied to today's Cross Lake (and associated creek/bayou) in the early 1800s would depend upon who you were talking to.

\section{Summary and Conclusions}

The village of the great caddi, Dehahuit, has long been thought to have been located north of Caddo Lake - in recent years opinion has coalesced around the site south of Jim's Bayou in Marion County. It is the view of the author that the archival record does not support the contention that this site was the home village of Dehahuit. Based on a variety of period materials including court filings, reports and letters from Indian agents, Mexican and Republic of Texas surveys and a memorial from the Caddo themselves, it seems clear that Dehahuit's village was located south of Paw Paw Bayou on the old Natchitoches-to-Pecan Point Road on the section line between Sections 2 and 3 of northwest Louisiana's T17N, R17W - a site that would later be found to lie approximately 2.5 miles west of the current Texas-Louisiana line. The village, situated approximately 1.75 miles northwest of Waskom, probably straddles Farm-to-Market Road 134 near the entrance to the Victoria Wood housing addition. 


\section{Notes}

1. The material in this article has been adapted from Tiller, Jr., James W. Before the Line: A Geographical Analysis of Selected Period Records From the Caddo Lake-Sabine River Borderland of Texas, 1803-1841. Vol. II. Caddo Indians: The Sodo Lakes Years (working manuscript).

2. See for instance, Bagur, Jacques. A History of Navigation on Cypress Bayou and the Lakes. Denton, TX: University of North Texas Press, 2001. pp. 30-39; Carter, Cecile Elkins. Caddo Indians: Where We Come From. Norman, OK: University of Oklahoma Press, 1995. pp. 214-217; Parsons, Mark L., James E. Bruseth, Jaques Bagur, S. Eileen Goldborer and Claude McCrocklin. Finding Sha'chahdinnih (Timber Hill): The Last Village of the Kadohadacho in the Caddo Homeland. Archeological Reports Series, No. 3. Austin, TX: Texas Historical Commission, 2002. pp. 5-14.

The Caddo site on Jim's Bayou is often represented in the literature as Timber Hill, the home of Dehahuit and the last Caddo village in their traditional northwest Louisiana and adjacent East Texas homeland. ${ }^{2.1}$ In fact, it was neither. ${ }^{2.2}$ There is no doubt the Jim's Bayou site was a very old and substantial settlement. This is probably the village depicted on Darby's 1816 Map of Louisiana, ${ }^{2.3}$ and may be the village near the Caddo Prairie Agency alluded to by Gray in $1824 .^{2.4}$ The site is depicted on the 1838 plat map of northwest Louisiana's T21N, R17W (Sections 2 and 11). ${ }^{2.5}$

2.1. A major source for much of the confusion regarding this site may be found in the recent work of Bagur (see his A History of Navigation on the Cypress Bayou and the Lakes [2001], and especially his material in Finding Sha'chahdinnih (Timber Hill): The Last Village of the Kadohadacho in the Caddo Homeland [2002], both cited above).

2.2. Tiller, Jim. Was Timber Hill the Last Caddo Village in the Caddo Homeland? Caddo Archeology Journal. Vol. 18 (2008). pp. 11-21. The author was in error in this article when suggesting that the name Timber Hill applied to the Jim's Bayou site.

2.3. A Map of the State of Louisiana with Part Of The Mississippi Territory, from Actual Survey By Wm. Darby. 1816. William Darby, surveyor. Philadelphia, PA: John Melish. The David Rumsey Map Collection (see URL, www.davidrumsey.com).

2.4. National Archives and Records Administration. Letters Received by the Office of Indian Affairs, 1824-1881, Red River Agency. M234, Roll 727. Letter from George Gray, Agent to Thomas McKinney, Superintendent of Indian Affairs, October 1, 1824.

2.5. United States Department of the Interior, Bureau of Land Management. Louisiana, North and West District. Survey Plat Map for T21N, R17W (1838). Paper copies (18" X 24") may be acquired from the Bureau of Land Management in Springfield, Virginia. Also available online at http://www.glorecords. blm.gov/ (see Search Surveys).

3. Pichardo, Father José Antonio. Charles Wilson Hackett (editor). Pichardo's Treatise on the Limits of Louisiana and Texas: An Argumentative Historical Treatise with Reference to the Verification of the True Limits of the Provinces of Louisiana and Texas: Written by Father José Antonio Pichardo, of the Congregation of the Oratory of San Felipe Neri, to Disprove the Claim of the United States That Texas Was Included in the Louisiana Purchase of 1803. Vol. III. Austin, TX: The University of Texas Press, 1946. p. 422.

4. For purposes of identification, the author has assigned names to Caddo sites discussed in this article not documented in period records. Unless indicated as a named village in Notes 5-18 below, the site designations are those of the author and should not in any way be taken as a name found in period documents. 


\section{Notes (cont.)}

5. The Jim's Bayou village is not a named Caddo village in period documents. The site (41MR211) is located on Jim's Bayou in northeastern Marion County approximately two miles west of the Texas-Louisiana border. ${ }^{5.1}$ While there is no reference made to the village in early Republic of Texas surveys, the site is found on the 1838 American survey straddling the section line of Sections 2 and 11, T21N, R17W..$^{5.2}$

5.1. Parsons, Mark L., James E. Bruseth, Jaques Bagur, S. Eileen Goldborer and Claude McCrocklin. Finding Sha'chahdinnih (Timber Hill): The Last Village of the Kadohadacho in the Caddo Homeland. Archeological Reports Series, No. 3. Austin, TX: Texas Historical Commission, 2002.

5.2. United States Department of the Interior, Bureau of Land Management. Louisiana, North and West District. Survey Plat Map for T21N, R17W (1838). Paper copies (18" X 24") may be acquired from the Bureau of Land Management in Springfield, Virginia. Also available online at http://www.glorecords. blm.gov/ (see Search Surveys).

6. The North Caddo village is a Caddo village named in period documents. The village site is located on Trammel's Trace near the intersection with the road from Shreveport via the Middle Caddo and Dehahuit's village. $^{6.1}$

6.1. See Texas General Land Office. Shelby County. First Class, File 000108, Josiah Prewitt; Shelby County. First Class, File 000090, R.O. Watkins. Original Land Grant Collection, Archives and Records Division, Austin, Texas.

7. The Middle Caddo village is a Caddo village named in period documents. The village site is located on Harrison Bayou on the Shreveport-to-Trammel's Trace Road between the North Caddo and Dehahuit's village. $^{7.1}$

7.1. See Texas General Land Office. Shelby County. First Class, File 000152, Holland Anderson; Shelby County. First Class, File 000185, Seaborn Robinson. Original Land Grant Collection, Archives and Records Division, Austin, Texas.

8. The Big Spring Caddo village is a named Caddo village in period documents. This village site is depicted in a general sense on an 1840 Texas General Land Office map. ${ }^{8.1}$ It is also referenced in a number of early Republic of Texas headright surveys. ${ }^{8.2}$ The village is mentioned by name in John S. "Rip" Ford's memoirs. ${ }^{8.3}$

8.1. Texas General Land Office. Map Collection. Harrison County. 1840. GLO Map Image 1515. Archives and Records Division, Austin, Texas.

8.2. See for instance, Texas General Land Office. Harrison County. Third Class, File 000184, Josiah Barrentine; Shelby County. First Class, File 000156, Lucinda Wallace; Shelby County. First Class, File 000174, Sarah Shoto; Shelby County. First Class, File 000278, James Cellums; Shelby County. First Class, File 000361, Sebastian C. Garner. Original Land Grant Collection, Archives and Records Division, Austin, Texas.

8.3. Ford, John Salmon. Stephen B. Oates (editor). Rip Ford's Texas. Austin, TX: The University of Texas Press, 1963. pp. 25-26.

9. Dehahuit's village is not a named Caddo village in period documents. It is depicted on the American survey plat on the section line between Sections 2 and 3, T17N, R17N. ${ }^{9.1}$ This is almost surely the village mentioned in Bonnell's report of April $1836^{9.2}$ as being located 12 miles from a second, more southerly, Caddo village (probably the Louisiana Caddo village, see Note 16). 


\section{Notes (cont.)}

9.1. United States Department of the Interior, Bureau of Land Management. Louisiana, North and West District. Survey Plat Map for T17N, R17W (1838). Paper copies (18" X 24") may be acquired from the Bureau of Land Management in Springfield, Virginia. Also available online at http://www.glorecords. blm.gov/ (see Search Surveys).

9.2. 25th Cong. 2nd sess. House Document 351. pp. 774-775, 807.

10. The Caddo Prairie Floodplain village is not a named Caddo village in period documents. In his journal, trader Anthony Glass noted that upon leaving the Cedar Bluff site he travelled approximately seven miles across what we know today as the Caddo Prairie. During the journey, he "saw the remains of Caddo Huts and many Peach trees." ${ }^{10.1}$ Although the location of this site has not been established (it probably having long ago been either washed away or silted over by the meandering Red River), its general location is clearly depicted on Alban \& Oliver's map entitled Route to Surround Red River Raft. ${ }^{10.2}$

10.1. Glass, Anthony. Dan L. Flores (editor). Journal of an Indian Trader: Anthony Glass and the Texas Trading Frontier, 1790-1810. Texas A\&M Southwestern Studies, No. 4. College Station, TX: Texas A\&M University Press, 1985. p. 41.

10.2. Route to Surround Red River Raft by contractors Alban \& Oliver (map). Under Act of the Legislature of the State of Louisiana to improve Red River Navigation, Approved September 8, 1869, With other data from the U.S. Historic Records. And engineering records of the War Department and the Louisiana Geological Survey. Archives and Special Collections, Noel Library, Louisiana State University, Shreveport. Shreveport, Louisiana.

11. The Cedar Bluff village is not a named Caddo village in period documents. During the summer of 1806, President Thomas Jefferson sent an expedition up the Red River to explore that portion of the recently acquired Louisiana Purchase. The expedition principals, Thomas Freeman and Peter Custis, both kept journals of their day-to-day activities. ${ }^{11.1}$ After a tortuous upstream trip around the eastern side of the Great Raft, both journalists upon re-entering the river recorded a series of events relating to the Caddo. Figuring prominently in their journal entries was the Coushatta village located at Cedar Bluff on the east side of the Red River some 25 miles north of present-day Shreveport. McCrocklin has identified this site as 16B0173. ${ }^{11.2}$ Glass described the Coushattas who occupied the site at the time of his trip through the region in 1808 as being "friendly with the Caddoes who own the Country \& who used to occupy the same spot."11.3 Flores reproduced Custis' "A List of Notable Points on the Middle and Upper Red River" in which Custis noted a distance of 80 miles (by the river) between the Little River (Sulphur Fork) and the "Conchetta villages [sic] (where the Cadoux lived, 9 years ago)."11.4 Sibley provided an identical figure, but he notes that the site was the "Late Caddo villages [sic] where they lived five years ago."11.5 While precise mileages by river cannot be determined more than 200 years after the events described, it certainly appears that the Coushatta village of Custis and that of Sibley is one in the same. Thus it appears that the Caddo occupied the Cedar Bluff site sometime between 1797 (Custis) and 1800 (Sibley).

11.1. Flores, Dan L. Jefferson \& Southwestern Exploration: The Freeman \& Custis Accounts of the Red River Expedition of 1806. Norman, OK: University of Oklahoma Press, 1984.

11.2. McCrocklin, Claude. "The Red River Coushatta Indian Villages of Northwest Louisiana 17901835." Louisiana Archeology. Vol. 12 (1985). pp. 129-178. 


\section{Notes (cont.)}

11.3. Glass, Anthony. Dan L. Flores (editor). Journal of an Indian Trader: Anthony Glass and the Texas Trading Frontier, 1790-1810. Texas A\&M Southwestern Studies, No. 4. College Station, TX: Texas A\&M Press, 1985. p. 39

11.4. Flores, Dan L. Jefferson \& Southwestern Exploration: The Freeman \& Custis Accounts of the Red River Expedition of 1806. Norman, OK: University of Oklahoma Press, 1984. p. 328.

11.5. Sibley, John. "Distances up Red River, by the Course of the River." American State Papers. Indian Affairs. Vol. I. pp. 730-731.

12. The Peach Orchard Bluff village is not a named Caddo village in period documents. The case for the possible existence of this village is based on the author's premise that Dehahuit's village is located on Paw Paw Bayou.

John Sibley noted in his "Historical Sketches" (April 1805) that the Caddo

settled on the river nearly opposite where they now live, on a low place, but were drove from there on account of its overflow, occasioned by a jam of Timber choking the river at a point below them. ${ }^{12.1}$

The author suggests that this village was located near the site Jehiel Brooks selected in 1830 for the new Caddo Agency - a point situated just south of modern-day Shreveport. The location was given the name

Peach Orchard Bluff due to the presence of peach trees growing in the area. ${ }^{12.2}$ The 1830-era Caddo Agency was located west of Bayou Pierre close to a site the French knew as "the Point."12.3 Its strategic location near where Bayou Pierre diverged from the Red River (along with the presence of peach trees which are assumed to have been closely associated with Caddo villages) would certainly suggest the possible presence of a late 1700s-early 1800s-era Caddo village nearby. The site was probably abandoned with the approach of the Great Raft which finally closed the Bayou Pierre chute in the spring of $1800 .{ }^{12.4}$

12.1. Sibley, John. "Historical Sketches of the Several Indian Tribes in Louisiana, South of the Arkansas River, and Between the Mississippi and River Grande." American State Papers. Indian Affairs. Vol. I. p. 721.

12.2. National Archives and Records Administration. Letters Received by the Office of Indian Affairs, 1824-1881, Caddo Agency. M234, Roll 31. Letter from Jehiel Brooks, Agent to John H. Eaton, Secretary of War, February 16, 1831.

12.3. Sibley, John. Letter to General Henry Dearborn, Secretary of War, April 10, 1805. American State Papers. Indian Affairs. Vol. I. p. 728.

12.4. We know from Sibley's 1805 "Historical Sketches" that the primary Caddo village on Paw Paw Bayou (Dehahuit's village) ${ }^{12.4 a}$ was first occupied prior to $1800,{ }^{12.4 b}$ the settlement having been relocated from a "low place" just above the Great Raft due to flooding. ${ }^{12.4 c}$ While Sibley suggested the flooding was due to debris choking the main stream, it seems more likely the flooding was related to the formation of the Sodo Lakes complex itself. Sibley's letter of November 28, 1812 suggests that the lakes had "been formed within about Twelve years ..." $12.4 \mathrm{~d}$ 


\section{Notes (cont.)}

12.4a. If, as the author contends, Dehahuit's village was located on Paw Paw Bayou (and we know from Brooks' answer to the memorial of Samuel Norris that Dehahuit lived in the same village from at least 1805 until his death in 1833), then, according to Sibley, his village was probably previously located to the east in a "low place," on or very near the Red River.

12.4b. Tiller, Jr., James W. Before the Line: A Geographical Analysis of Selected Period Records From the Caddo Lake-Sabine River Borderland of Texas, 1803-1841. Vol. II. Caddo Indians: The Sodo Lakes Years (working manuscript).

12.4c. Sibley, John. "Historical Sketches of the Several Indian Tribes in Louisiana, South of the Arkansas River, and Between the Mississippi and River Grande." American State Papers. Indian Affairs. Vol I. p. 721. See also Sibley, John. Letter to General Henry Dearborn, Secretary of War. April 10, 1805. American State Papers. Indian Affairs. Vol. I. p. 728.

12.4d. National Archives and Records Administration. Letters Received by the Secretary of War, main series, 1801-1870. M221, Reel 57. Letter from John Sibley, Agent to William Eustis, Secretary of War, November 28, 1812. Material courtesy the University of Southern Mississippi. Hattiesburg, MS. See also Bagur, Jacques. A History of Navigation on Cypress Bayou and the Lakes. Denton, TX: University of North Texas Press, 2001. pp. 11-13; Garrett, Julia Kathryn. "Dr. John Sibley and the Louisiana-Texas Frontier, 1803-1814." Southwestern Historical Quarterly. Vol. 49, No. 3 (January 1946). pp. 417-418.

13. Agent Sewall's Caddo village is not a named Caddo village in period documents, and the information

provided in the literature as to the location of this village is too vague to offer much in the way of where this site may have been. The archival record tells us that the Caddo came to Shreveport in the fall of 1838 to collect their annual annuity. Difficulties with Texans prohibited them from returning to their settlements in Texas. For their safety, Caddo Agent Charles Sewall placed the Caddo in "winter quarters"

... on an extensive Island formed by the chain of Great Lakes \& the Red River - a section of Country unoccupied by the whites and abounding in Game ... ${ }^{13.1}$

Because most of the larger "island" areas to the south of Shreveport were already settled (for instance, Rush Island), it appears likely that Agent Sewall's village was situated north of the town. The descriptors used suggest the site must have been situated in a relatively undesirable area, and the narrow region between the Red River and the lakes would have offered many such locations.

13.1. National Archives and Records Administration. Letters Received by the Office of Indian Affairs, 1824-1881, Caddo Agency. M234, Roll 31. Letter from Charles Sewall, Agent to the Commissioner of Indian Affairs, January 8, 1839.

14. Col. Many's Caddo village is not a named Caddo village in period documents. Once (Texas) General Rusk and the Caddo had signed the November 29, 1838 treaty requiring the Caddo to remain in the United States, ${ }^{14.1}$ (American) Col. James B. Many, concerned about the destitute condition of the tribe

... authorized the Chief to occupy a small peninsula between Cross and Sodo Lakes on Red River, on which there are no white settlements, where his people might subsist by hunting and fishing until otherwise directed..$^{14.2}$ 


\section{Notes (cont.)}

While it is not possible as of this writing to locate with any specificity this site, it very likely will be found to lie on the north side of Cross Lake, south of Blanchard, between Shettleworth and Choctaw Bayous. ${ }^{14.3}$

14.1. National Archives and Records Administration. Letters Received by the Office of Indian Affairs, 1824-1881, Caddo Agency. M234, Roll 31. Treaty between General Thomas J. Rusk and the Caddo Indians, November 29, 1838.

14.2. National Archives and Records Administration. Letters Received by the Office of Indian Affairs, 1824-1881, Caddo Agency. M234, Roll 31. Letter from Col. James B. Many, 3rd Infantry to Joel R. Poinsett, Secretary of War, April 19, 1839.

14.3. Royce, Charles C. (compiler). Map of Louisiana Cessions in Indian Land Cessions in the United States. Bureau of American Ethnology, Eighteenth Annual Report, 1896-1897 (Part 2). Smithsonian Institution. See Library of Congress, call number E51.U55 18th. (see URL, http://lcweb2.loc.gov/ cgi-bin/map_item.pl?data=/home/www/data/gmd//gmd370m/g3701m/g3701em/gct00002/ ca000028.jp2\&style=gmd\&itemLink=r?ammem/gmd:@field(NUMBER+@band(g3701em+gct0000 2))\&title=Indian $\% 20$ land $\% 20$ cessions $\% 20$ in $\% 20$ the $\% 20$ United $\% 20$ States, $\% 20$ comp. $\% 20$ by $\% 20$ Charles\%20C.\%20Royce,\%20with\%20introduction\%20by\%20Cyrus\%20Thomas.+-+Louisiana).

15. The Border village is not a named Caddo village in period documents. This village site is located on a tributary of Harrison Bayou some two miles northeast of the Middle Village on a road between that village and Shenick's Ferry on Caddo Lake. ${ }^{15.1}$ The settlement is depicted on the 1838 plat map of northwest Louisiana's T18N, R17W (extreme western edge of Section 6). Due to its proximity to the Middle village, it is possible that this site was a part of the Middle Village complex. ${ }^{15.2}$

15.1. Texas General Land Office. Shelby County. First Class, File 000185, Seaborn Robinson. Original Land Grant Collection, Archives and Records Division, Austin, Texas.

15.2. United States Department of the Interior, Bureau of Land Management. Louisiana, North and West District. Survey Plat Map for T18N, R17W (1838). Paper copies (18" X 24") may be acquired from the Bureau of Land Management in Springfield, Virginia. Also available online at http://www. glorecords.blm.gov/ (see Search Surveys); Texas General Land Office. Shelby County. First Class, File 000185, Seaborn Robinson. Original Land Grant Collection, Archives and Records Division, Austin, Texas.

16. The Louisiana village is not a named Caddo village in period documents. It is depicted on the 1838 plat map of northwest Louisiana's T16N, R16W (Section 35). ${ }^{16.1}$ This is probably the village mentioned in Bonnell's report of April 1836 as being located 12 miles from a second, more northerly, Caddo village ${ }^{16.2}$ (see the Dehahuit's Caddo village, Note 9).

16.1. United States Department of the Interior, Bureau of Land Management. Louisiana, North and West District. Survey Plat Map for T18N, R17W (1838). Paper copies (18" X 24") may be acquired from the Bureau of Land Management in Springfield, Virginia. Also available online at http://www. glorecords.blm.gov/ (see Search Surveys).

16.2. 25th Cong., 2nd sess. House Document 351. p. 807. 


\section{Notes (cont.)}

17. The Small village is not a named Caddo village in period documents. The location of the Small village site is known in a general sense from a reference made in a nearby Republic of Texas survey. The village, situated one-half mile west of the William R.D. Ward survey, was described as "a small Indian village on the waters of a Creek emptying into Haggarties Bayou a tributary of Lake Sodo." ${ }^{17.1}$ Based upon its proximity to other known historic-era Caddo villages, this site may be Caddo.

17.1. Texas General Land Office. Shelby County. First Class, File 000157, William R.D. Ward. Original Land Grant Collection, Archives and Records Division, Austin, Texas.

18. The Mooringsport "village" is not a named Caddo village in period documents. In fact, it is not at all clear that this is even a village. The site lies just west of Mooringsport, Louisiana in Section 9, T19N, R16W on what was once a large prairie. ${ }^{18.1}$ In the 1830 s period, this site would have been in close proximity to a trail leading to the major crossing on Sodo Lake. While we give this entity the name "Mooringsport village," we strongly suspect the site depicted is actually a pine hill.

18.1. Delgado, Miguel. Spanish Collection, Land Survey, SC000115:12. Archives and Records Division. Texas General Land Office. Austin, Texas; A comparison of Delgado's survey with a modern topographic map (see United States Geological Survey. Mooringsport, Louisiana. Topographic Map Series, 1:24,000, 7.5 Minute Series. Washington, D.C.: United States Government Printing Office, 1982) places the "village" in question just south of Tete Bayou on a small, isolated hill located northwest of the center of Section 9, T19N, R16W.

19. United States Department of the Interior, Bureau of Land Management. Louisiana, North and West District. Survey Plat Maps and Field Notes for the following: T12N, R16W (1837), T13N, R16W (1837), T14N, R16W (1837), T15N, R16W (1837), T16N, R16W (1837), T17N, R16W (1837), T18N, R16W (1838), T19N, R16W (1838), T20N, R16W (1837), T21N, R16W (1837), T22N, R16W (1839), T23N, R16W (1839); T12N, R17W

(1837) (brief notes on extending a line west from the 3rd mile post of T12N, R16W), T12N, R17W (1839) (field notes only), T13N, R17W (1838), T14N, R17W (1838), T15N, R17W (1838), T16N, R17W (1838), T17N, R17W (1838), T18N, R17W (1838), T19N, R17W (1838), T20N, R17W (1839), T21N, R17W (1838), T22N, R17W (1839), T23N, R17W (1839). Available from the Bureau of Land Management, Springfield, Virginia. Paper copies (18" X 24") may be acquired from the Bureau of Land Management in Springfield, Virginia. Also available online at http://www.glorecords.blm.gov/ (see Search Surveys).

20. Flores, Dan L. (editor). Jefferson \& Southwestern Exploration: The Freeman \& Custis Accounts of the Red River Expedition of 1806. Norman, OK: University of Oklahoma Press, 1984. pp. 145-146, 148.

21. Pichardo, Father José Antonio. Charles Wilson Hackett (editor). Pichardo's Treatise on the Limits of Louisiana and Texas: An Argumentative Historical Treatise with Reference to the Verification of the True Limits of the Provinces of Louisiana and Texas: Written by Father José Antonio Pichardo, of the Congregation of the Oratory of San Felipe Neri, to Disprove the Claim of the United States That Texas Was Included in the Louisiana Purchase of 1803. Vol. III. Austin, TX: The University of Texas Press, 1946. pp. 422-429.

22. Brooks, Jehiel. The Answer of Jehiel Brooks to the Memorial of Samuel Norris, January 30, 1840. Box 1, Folder 12, Item 8, The Brooks-Queen Family Collection. The American Catholic History Research Center and University Archives. The Catholic University of America. Washington, D.C. (see URL, www.aladin.wrlc.org/ gsdl/collect/brooks/brooks.shtml). 


\section{Notes (cont.)}

23. In the land cession of 1835, the Caddo designated in Supplementary Article I (see also the preamble of these supplementary articles) that the heirs of Francois Grappe (known to the Caddo as Touline), their longtime interpreter and advisor, be granted four leagues of land (almost 18,000 acres) lying between the main channel of the Red River and Bayou Pierre north of Pascagoula Bayou. ${ }^{23.1}$ In the years following the treaty, Jehiel Brooks, the U.S. Commissioner who negotiated the Caddo cession, purchased the land on Rush Island from the Grappe family. His attempts to evict a number of Rush Island settlers on the land set in motion a series of legal actions that ultimately resulted in a Supreme Court of the United States opinion favorable to Brooks. ${ }^{23.2}$ The associated memorials, court filings and decisions offer the researcher a wealth of information on the Caddo during their years in the Sodo Lakes region. ${ }^{23.3}$

23.1. Brooks, Jehiel. The Answer of Jehiel Brooks to the Memorial of Samuel Norris, January 30, 1840. Box 1, Folder 12, Item 8, The Brooks-Queen Family Collection. The American Catholic History Research Center and University Archives. The Catholic University of America. Washington, D.C. (see URL, www. aladin.wrlc.org/gsdl/collect/brooks/brooks.shtml).

23.2. United States vs Jehiel Brooks et al. 51 U.S. 442 (1850).

23.3. Tiller, Jr., James W. Before the Line: A Geographical Analysis of Selected Period Records From the Caddo Lake-Sabine River Borderland of Texas, 1803-1841. Vol. II. Caddo Indians: The Sodo Lakes Years (working manuscript).

24. Brooks, Jehiel. The Answer of Jehiel Brooks to the Memorial of Samuel Norris, January 30, 1840. Box 1, Folder 12, Item 8, The Brooks-Queen Family Collection. The American Catholic History Research Center and University Archives. The Catholic University of America. Washington, D.C. (see URL, www.aladin.wrlc.org/ gsdl/collect/brooks/brooks.shtml).

25. 27th Cong., 2nd sess. House Report 1035. pp. 73-74.

26. United States Department of the Interior, Bureau of Land Management. Louisiana, North and West District. Survey Plat Maps and Field Notes for T16N, R16W (1837). Available from the Bureau of Land Management, Springfield, Virginia. Also available online at http://www.glorecords.blm.gov/ (see Search Surveys).

27. United States Department of the Interior, Bureau of Land Management. Louisiana, North and West District. Survey Plat Maps and Field Notes for the following: T9N, R8W (1831), T9N, R9W (1830), T9N, R10W (1855), T10N, R10W (1831), T11N, R10W (1831), T11N, R11W (1832), T12N, R11W (1833), T12N, R12W (1832), T13N, R12W (1832), T13N, R13W (1832), T14N, R13W (1835), T15N, R13W (1833), T15N, R14W(1832), T16N, $R 14 W$ (1846), T16N, R15W (1847), T17N, R16W (1839), T17N, R17W (1839), T18N, R17W (1839). Dates are taken from material provided on the BLM site. For a more specific field completion date see Figure 2 and the field notes for the specific survey. Available from the Bureau of Land Management, Springfield, Virginia. Also available online at http://www.glorecords.blm.gov/ (see Search Surveys). See also Louisiana, State Land Office. Northwestern District. Survey Plat Maps and Field Notes for T9N, R7W (1825).

28. Sibley, John. "Historical Sketches of the Several Indian Tribes in Louisiana, South of the Arkansas River, and Between the Mississippi and River Grande." American State Papers. Indian Affairs. Vol I. p. 721.

29. Bagur, Jacques. A History of Navigation on Cypress Bayou and the Lakes. Denton, TX: University of North Texas Press, 2001. pp. 18-20. 


\section{Notes (cont.)}

30. United States Geological Survey data for the 1996 to present period indicates high water events on Cross Lake range between 172 and 175 feet. $^{30.1}$

30.1. See URL, http://waterdata.usgs.gov/la/nwis/dv?cb_00065=on\&format=gif_default\&begin_ date=1996-08-01\&end_date=2009-09-29\&site_no=07344480\&referred_module $=$ sw

31. The Wallace family was one of the pioneering middle Red River valley families having lived in the area since the late $1700 \mathrm{~s}^{31.1}$ As a resident of Natchitoches, and an individual interested in Indian matters, Sibley would have had the occasion to have made the acquaintance of many members of this family.

31.1. 27th Cong., 2nd sess. House Report 1035. p. 24; Terán, Manuel de Mier y. Jack Jackson (editor), John Wheat (translator). Texas by Terán: The Diary Kept by General Manuel de Mier y Terán on His 1828 Inspection of Texas. Austin, TX: The University of Texas Press, 2000. pp. 249-250; 19th Cong. 2nd sess. House Report 102. pp. 19-21.

32. National Archives and Records Administration. Letters Received by the Office of Indian Affairs, 1824-1881, Caddo Agency. M234, Roll 31. Memorial from the Chiefs and Head Men of the Caddo Nation to the Secretary of War, January 9, 1837.

\section{27th Cong., 2nd sess. House Report 1035. p. 76.}

34. The phrase "first red water" refers to the first stream carrying the distinctive red water associated with the Red River. Prior to June 1833 when Henry Shreve cleared the Great Raft from the old channel of the Red River up to the area of Shreveport, much of the water of that river was actually passed south via Bayou Pierre. It was the contention of the Rush Island settlers that the Caddo boundary was not the Red River, but rather Bayou Pierre. They argued that the lands acquired from the Caddo did not include their improvements on Rush Island. In effect, the Caddo had no right to set aside a reservation for the Grappe family - thus Brooks had no claim to the lands on Rush Island.

Clearly, the Islanders were not aware of the many legal precedents/technicalities ${ }^{34.1}$ and previous correspondence between Agent George Gray and the United States government in the mid-1820s which "set aside" a specific area for the Caddo. Gray suggested the boundaries of these lands extended

... from Sulphur Fork to a large Creek called cypress Creek and is now generally known as the Caddoes's boundary line. No whites have any claim to lands within that boundary. ${ }^{34.2}$

... at the mouth of Sulphur Fork thence, meandering, the old channel of Red River to its junction with the Cypress Bayou on the east and the Cypress Bayou on the southeast, Sulphur Fork on the west, and the Spanish line on the southwest, those lines are natural ones and generally understood as the boundary of the Caddo Lands by both Indians and Whites. ${ }^{34.3}$

In addition, it appears Poissoit, Valentin and Laffitte were not aware of what the Caddo believed they had ceded to the United States (see Notes 35-37). From their description, these individuals clearly equated Terán's Line with the eastern boundary of the Caddo cession (from the line "thence west," or "out towards sunset"). The Caddo considered it the western boundary of the lands ceded. The comments of Poissoit and 


\section{Notes (cont.)}

the other deponents are somewhat understandable when one considers that all were testifying in support of Samuel Norris and in effect against Jehiel Brooks who was attempting to evict Norris and others from the four-league parcel of land on Rush Island Brooks had purchased from the Grappe family. A boundary such as that defined by these individuals would have placed Rush Island outside the Caddo lands.

Of course, neither Brooks nor the American government recognized Terán's Line as a legitimate boundary. In the 1835 treaty, the western boundary of the Caddo lands were defined as

Bounded on the west by the north and south line which separates the said United States from the Republic of Mexico, between the Sabine and Red rivers wheresoever the same shall be defined and acknowledged to be by the two governments. ${ }^{34.4}$

Brooks, in his summation to the District Court jury, went right to the heart of the testimony of Poissoit, Valentin and Laffitte when he noted that

some of the witnesses assert that the Caddos only intended to sell west of Terán's line, which, if that line was correct, would have been selling nothing, as all west of it would have been in Mexico..$^{34.5}$

While the Caddo may have hoped that Terán's Line would be the western boundary of their lands (thus, as noted in the text of the article, permitting them to keep all of their villages), such was not to be the case.

34.1. United States vs Jehiel Brooks et al. 51 U.S. 442 (1850).

34.2. National Archives and Records Administration. Letters Received by the Office of Indian Affairs, 1824-1881, Red River Agency. M234, Roll 727. Letter from George Gray, Agent to the Secretary of War, May 26, 1825.

34.3. National Archives and Records Administration. Letters Received by the Office of Indian Affairs, 1824-1881, Red River Agency. M234, Roll 727. Letter from George Gray, Agent to James Barbour, Secretary of War, September 30, 1825.

34.4. 27th Cong., 2nd sess. House Report 1035. pp. 74-75.

34.5. Brooks, Jehiel. Summation to the Jury, ca. May 1840 in the case of Jehiel Brooks vs Samuel Norris, District Court of Caddo Parish. Box 2, Folder 2, Item 1, The Brooks-Queen Family Collection. The American Catholic History Research Center and University Archives. The Catholic University of America. Washington, D.C. (see URL, www.aladin.wrlc.org/gsdl/collect/brooks/brooks.shtml).

35. 27th Cong., 2nd sess. House Report 1035. pp. 29-30.

36. 27th Cong., 2nd sess. House Report 1035. pp. 27-29.

37. 27th Cong., 2nd sess. House Report 1035. pp. 34-35.

38. Surveys between the Sabine and Red Rivers made for titles under Radford Berry, Commissioner. Atlas Collection, Document 14. Professional Services Program Area, Surveying Division. Texas General Land Office. Austin, Texas. 


\section{Notes (cont.)}

39. Tiller, Jr., James W. Before the Line: A Geographical Analysis of Selected Period Records From the Caddo Lake-Sabine River Borderland of Texas, 1803-1841. Vol. I. An Annotated Atlas of International Boundaries and Republic of Texas Administrative Units (forthcoming).

40. Brooks, Jehiel. Summation to the Jury, ca. May 1840 in the case of Jehiel Brooks vs Samuel Norris, District Court of Caddo Parish. Box 2, Folder 2, Item 1, The Brooks-Queen Family Collection. The American Catholic History Research Center and University Archives. The Catholic University of America. Washington, D.C. (see URL, www.aladin.wrlc.org/gsdl/collect/brooks/brooks.shtml).

41. Brooks, Jehiel. Summation to the Jury, ca. May 1840 in the case of Jehiel Brooks vs Samuel Norris, District Court of Caddo Parish. Box 2, Folder 2, Item 1, The Brooks-Queen Family Collection. The American Catholic History Research Center and University Archives. The Catholic University of America. Washington, D.C. (see URL, www.aladin.wrlc.org/gsdl/collect/brooks/brooks.shtml).

42. 27th Cong., 2nd sess. House Report 1035. pp. 103-105.

43. Brooks, Jehiel. Summation to the Jury, ca. May 1840 in the case of Jehiel Brooks vs Samuel Norris, District Court of Caddo Parish. Box 2, Folder 2, Item 1, The Brooks-Queen Family Collection. The American Catholic History Research Center and University Archives. The Catholic University of America. Washington, D.C. (see URL, www.aladin.wrlc.org/gsdl/collect/brooks/brooks.shtml).

44. Brooks, Jehiel. Summation to the Jury, ca. May 1840 in the case of Jehiel Brooks vs Samuel Norris, District Court of Caddo Parish. Box 2, Folder 2, Item 1, The Brooks-Queen Family Collection. The American Catholic History Research Center and University Archives. The Catholic University of America. Washington, D.C. (see URL, www.aladin.wrlc.org/gsdl/collect/brooks/brooks.shtml).

45. United States Department of the Interior, Bureau of Land Management. Williams and Terrell, Articles of Agreement for Surveying R17W. April 1, 1837. Springfield, Virginia.

46. 27th Cong., 2nd sess. House Report 1035. p. 74.

47. Concerns expressed by Texas settlers about Indian depredations during and in the period following the Revolution ${ }^{47.1}$ caused General Gaines to restrain the Caddo from migrating west as required by the 1835 treaty. Gaines sent at least two fact-finding expeditions into Caddo country to ascertain conditions among the tribe. The reports of both Lt. Bonnell (April 1836) (7.2 $^{47}$ and Major Riley (August 1836) ${ }^{47.3}$ found the Caddo peaceful and did not perceive them to represent a threat to the frontier populations. These reports apparently caused Gaines to grant permission for the Caddo to begin their migration westward sometime during the fall of that year, probably after difficulties with their agent Jehiel Brooks over their annual annuity had subsided. ${ }^{47.4}$

47.1. 25th Cong., 2nd sess. House Document 351. pp. 773-775.

47.2. 25th Cong., 2nd sess. House Document 351. pp. 774-775, 807.

47.3. 25th Cong., 2nd sess. House Document 351. pp. 815-818.

47.4. 27th Cong., 2nd sess. House Report 1035. pp. 36-37; copies of letters from John G. Green, J.C. McLeod and Jehiel Brooks, January 10, 1837 and January 26, 1837. Box 1, Folder 9, Item 8, The BrooksQueen Family Collection, American Catholic History Research Center and University Archives, 


\section{Notes (cont.)}

Catholic University of America. Washington, D.C. (see URL, www.aladin.wrlc.org/gsdl/collect/ brooks/brooks.shtml).

48. 25th Cong., 2nd sess. House Document 351. pp. 815-818.

49. Azco (Arco), Santos de. See GA 120-0023; GA 120-0068; GA 122-00216; GA 127-00575 GA 127-00578; GA 128-00659, 85-1. George Antonio Nixon Collection. Special Collections, The University of Texas at Arlington Library. Arlington, Texas.

50. 25th Cong. 2nd sess. House Document 351. pp. 815-816.

51. Texas General Land Office. Shelby County. First Class, File 000187, Francisco Valmore. Original Land Grant Collection, Archives and Records Division, Austin, Texas. This survey served as an anchor point for several adjoining surveys completed during the early spring months of 1838. On March 5, 1838, Lewis Watkins surveyed a tract for Holland Anderson that joined the Valmore-Smith survey on the north. In the general reference section of the field notes, Watkins observed that the southeastern corner of the survey (which adjoined the northeastern corner of Valmore's survey) was located

... about 2 or 3 miles S.E. of the Middle Caddo village, 2340 varas S. of the road leading from said village to Shreavesport ...51.1

Upon filing his notes with the Shelby County Clerk, this particular section was re-written (probably by threcording clerk) to read

... about 2000 varas of the East Caddo Village, 2340 varas south of the road leading from said village to Shreavesport ....

On April 13, 1838, Lewis Watkins surveyed a tract for Jeddiah Payne that joined Holland Anderson's tract on the east. In the notes Watkins observed that the survey began on

... the northeast corner of a survey marked J.S. [James Smith] know[n] also by the name of Big Spring village survey and the S.E. corner of Holland Anderson's survey ... ${ }^{51.3}$

While the Payne field notes were certified on May 1,1838, they were withdrawn by Watkins on August 11 of that year

... on plea that the whole of the land has been taken in by the U. States. ${ }^{51.4}$

Lewis Watkins was a Shelby County deputy surveyor who at the time lived in what is today Shelby County. The Anderson (and Payne) surveys were some of Watkins' earliest efforts in present-day Harrison County (the Land Office opened for surveys on February 1,1838). While Shelby County Deputy Surveyor John S."Rip" Ford (who surveyed the Valmore-Smith league on February 22,1838) was aware of the presence and name of the Big Spring village on upper Paw Paw Bayou (probably because his survey party was accompanied by local resident John Graves who we know from Ford's memoirs wished to own the lands around the village), ${ }^{51.5}$ newly-arrived Watkins was not. 


\section{Notes (cont.)}

Why did the Shelby County Clerk use the name East Caddo and not Big Spring village? It appears that when the Clerk made the correction to Watkins' field notes (sometime between March 5 and April 13), he was not aware of the name Big Spring village - although he certainly was aware of the presence of the village and the relative location of other villages in the area (the larger villages would have been landmarks well known to local inhabitants). He would not have called the Big Spring village the South village - that name was already accounted for. Too, he doubtless knew of American intentions to survey R17W which would include the South (Dehahuit) village. Removing that village from Texas proper (but still giving deference to the name South village as used by local inhabitants), the name East Caddo village was a reasonable name to have used considering his knowledge of area villages and barring any information as to a specific name for what was to become known as the Big Spring village.

We know from his memoirs (and the many late winter-early spring eastern Harrison County surveys bearing his signature), ${ }^{51.6}$ that Ford likely did not return to Shelbyville until sometime in late spring. It was at this point that the Clerk would have become aware of a local name for the Big Spring village. Watkins, who continued surveying in eastern Harrison County during the spring months, doubtless at some point prior to April 13 learned of the Big Spring name and began to use it.

As an aside, but of interest regarding the undefined Texas-United States boundary in this area, on April 12 (one day before Watkins surveyed the Payne tract which lay in what was to become T18N, R17W), American surveyors platted the north boundary of T18N, R16. ${ }^{51.7}$ Because Dehahuit's village lay within two miles of the southwestern boundary of this township, it would have been apparent to all that the village would fall within the bounds of the United States once the survey of T17N, R17W was completed. The survey of T18N, R17W began on May 3 and was probably completed within two weeks. ${ }^{51.8}$ Watkins acknowledged the superior jurisdiction of the American surveys in R17W with his August 11 comment regarding Payne's survey.

51.1. Texas General Land Office. Shelby County. First Class, File 000152, Holland Anderson. Original Land Grant Collection, Archives and Records Division, Austin, Texas.

51.2. Texas, Harrison County. Survey Record Book A. pp. 22-23.

51.3. Texas, Harrison County. Survey Record Book A. p. 91.

51.4. Texas, Harrison County. Survey Record Book A. p. 92.

51.5 Ford, John Salmon. Stephen B. Oates (editor). Rip Ford's Texas. Austin, TX: The University of Texas Press, 1963. p. 25.

51.6. Ford, John Salmon. Stephen B. Oates (editor). Rip Ford's Texas. Austin, TX: The University of Texas Press, 1963. pp. 25-27; see also some 17 late February through early May 1838 surveys by John Ford in Texas Harrison County. Survey Record Book A, pp. 4, 6-7, 36-37, 42-43, 43-44, 139, 142-143, 182-191.

51.7. United States Department of the Interior, Bureau of Land Management. Louisiana, North and West District. Field Notes for T18N, R16W (1838). Paper copies (18" X 24") may be acquired from the Bureau of Land Management in Springfield, Virginia. Also available online at http://www.glorecords. blm.gov/ (see Search Surveys). 


\section{Notes (cont.)}

51.8. United States Department of the Interior, Bureau of Land Management. Louisiana, North and West District. Field Notes for T18N, R17W (1838). Paper copies (18" X 24") may be acquired from the Bureau of Land Management in Springfield, Virginia. Also available online at http://www.glorecords. blm.gov/ (see Search Surveys).

\section{See Note 8.}

53. Tiller, Jr., James W. and Albert Wayne Tiller. Our American Adventure: The History of a Pioneer East Texas Family, 1657-1966. Huntsville, TX: The START Group, 2008. pp. 101-121.

54. Petition from Citizens of Red River County to the Congress of the Republic of Texas, March 11, 1837. Memorials and Petitions. Manuscript Collections, Archives and Information

Services Division, Texas State Library and Archives Commission, Austin, Texas; Tiller, James Weeks. "The March 11, 1837 Petition to the Congress of the Republic of Texas for the Creation of a New County Called Green." Stirpes, the Quarterly Journal of the Texas State Genealogical Society. Vol. 47 (December 2007). pp. 5-17.

55. Evidence that Caddo were still to be found in the area would include comments made by John S. "Rip" Ford in his memoir. Ford, a Deputy Surveyor for Shelby County, was making his way through what would become eastern Harrison County in February-March 1838, when he stopped at the "Big Spring village" - a village "inhabited by Caddo Indians." He also noted that "within a radius of twenty miles there were three or four Indian towns." ${ }^{55.1}$ Earlier, on March 11, 1837, 108 individuals, most of whom lived south of Caddo Lake and east of Trammel's Trace, sent a petition to the Congress of the Republic of Texas seeking the creation of a new county and land office. While the petitioners indicated that "we are all living without law or regulations amongst us," no mention was made of any difficulties with Indians. ${ }^{55.2}$

55.1. Ford, John Salmon. Stephen B. Oates (editor). Rip Ford's Texas. Austin: The University of Texas Press, 1963. pp. 25-26.

55.2. Petition from Citizens of Red River County to the Congress of the Republic of Texas, March 11, 1837. Memorials and Petitions. Manuscript Collections, Archives and Information Services Division, Texas State Library and Archives Commission, Austin, Texas.

56. For references to the North Caddo village see Note 6. In at least one instance, this village was referred to as the Upper Caddo village. ${ }^{56.1}$

56.1. Texas, Harrison County. District Court. Survey Record Book A. p. 128.

57. The reader will remember that Jehiel Brooks did provide a name for Dehahuit's village - "the Key village." This may well have been the name used by Brooks as well as those he was most in contact with - Louisiana residents living in the area between the Caddo Agency and Natchitoches. For such individuals, the designation "South" would have had little meaning. From their perspective, Dehahuit's village was not the most southern Caddo village (that being the un-named in period documents Louisiana village). However, as the home of the great Caddo chief, Dehahuit's village would have been a place of significance (read as "Key," "most important," "primary or main") for both Brooks, whose responsibilities included seeing to the well-being of the Caddo, as well as local residents, whose activities within the Caddo lands would have been subject to Brooks' scrutiny. While research efforts in the records of Caddo Parish have to date turned up no reference to Dehahuit's village, it is the opinion of the author, as of this writing, that "Key village" was the name used by Louisiana residents to identify what Texas settlers knew as the South Caddo village. 


\section{Notes (cont.)}

58. 19th Cong. 2nd sess. House Report 102.pp. 19-21.

59. 27th Cong. 2nd sess. House Report 1035. p. 24.

60. See Notes 5-18 for the location of the Indian villages. The Sulphur Fork Factory/Agency was described as being

...just below the junction of this river [the Sulphur Fork with the Red River] there

is a high Bluff, on the west side of red river, about half a mile in length. ${ }^{60.1} \ldots$ For one

mile and a quarter below the Fork the Bluff is from eight to eighty feet above high water. ${ }^{60.2}$

The Caddo Prairie agency, located in Section 24, T21N, R15W, is depicted on Alban and Oliver's map. ${ }^{60.3}$ The Caddo Agency is located approximately six miles south of Shreveport near the present-day community of Forbing near the section line for Sections 7 and 8, T16N, R14W. ${ }^{60.4}$ The roads depicted on Figure 1 in Louisiana are adapted from Note 19. For those in Texas, see Note 60.5.

60.1. National Archives and Records Administration. Letterbook of the Natchitoches-Sulphur Fork Factory. M234, Roll T-1029. Letter from James Fowler, Factor to Thomas L. McKenney, Superintendent of Indian Trade, May 9, 1817. p. 115.

60.2. National Archives and Records Administration. Letterbook of the Natchitoches-Sulphur Fork Factory. M234, Roll T-1029. Letter from James Fowler, Factor to Thomas L. McKenney, Superintendent of Indian Trade, June 25, 1818. p. 144.

60.3. Route to Surround Red River Raft by contractors Alban \& Oliver (map). Under Act of the Legislature of the State of Louisiana to improve Red River Navigation, Approved September 8, 1869, With other data from the U.S. Historic Records. And engineering records of the War Department and the Louisiana Geological Survey. Archives and Special Collections, Noel Library, Louisiana State University, Shreveport. Shreveport, Louisiana.

60.4. The Caddo Agency is depicted on George Morse's 1842 survey plat map. See Hardin, J. Fair. "An Outline of Shreveport and Caddo Parish History." The Louisiana Historical Quarterly. Vol. 18, No. 4 (October 1935). p. 22.

60.5. See Texas General Land Office. Map Collection. Harrison District. 1840. GLO Map Image 1515, and Harrison County. 1846. GLO Map Image 1460. Archives and Records Division, Austin, Texas; Tiller, Jr., James W. and Albert Wayne Tiller. Our American Adventure: The History of a Pioneer East Texas Family, 1657-1966. Huntsville, TX: The START Group, 2008. pp. 172-205.

61. See Notes 5-18 for the location of the Indian villages; United States Department of the Interior, Bureau of Land Management. Louisiana, North and West District. Survey Plat Maps and Field Notes for the following: T12N, R16W (1837), T13N, R16W (1837), T14N, R16W (1837), T15N, R16W (1837), T16N, R16W (1837), T17N, R16W (1837), T18N, R16W (1838), T19N, R16W (1838), T20N, R16W (1837), T21N, R16W (1837), $T 22 N, R 16 W$ (1839), T23N, R16W (1839); T12N, R17W (1837) (brief notes on extending a line west from the 3rd mile post of T12N, R16W), T12N, R17W (1839) (field notes only), T13N, R17W (1838), T14N, R17W (1838), T15N, R17W (1838), T16N, R17W (1838), T17N, R17W (1838), T18N, R17W (1838), T19N, R17W (1838), T20N, R17W (1839), T21N, R17W (1838), T22N, R17W (1839), T23N, R17W (1839). Available from the 


\section{Notes (cont.)}

Bureau of Land Management, Springfield, Virginia. Paper copies (18" X 24") may be acquired from the Bureau of Land Management in Springfield, Virginia. Also available online at http://www.glorecords.blm.gov/ (see Search Surveys).

62. United States Department of the Interior, Bureau of Land Management. Louisiana, North and West District. Survey Plat Maps and Field Notes for T21N, R16W (1837) and T21N, R17W (1838). Available from the Bureau of Land Management, Springfield, Virginia. Paper copies (18" X 24") may be acquired from the Bureau of Land Management in Springfield, Virginia. Also available online at http://www.glorecords.blm.gov/ (see Search Surveys); United States Geological Survey. Trees, Texas (and adjacent quads). Topographic Map Series, 1:24,000, 7.5 Minute Series. Washington, D.C.: United States Government Printing Office, 1962.

63. United States Department of the Interior, Bureau of Land Management. Louisiana, North and West District. Survey Plat Maps and Field Notes for T17N, R16W (1837) and T17N, R17W (1838). Available from the Bureau of Land Management, Springfield, Virginia. Paper copies (18" X 24") may be acquired from the Bureau of Land Management in Springfield, Virginia. Also available online at http://www.glorecords.blm.gov/ (see Search Surveys); United States Geological Survey. Waskom, Texas (and adjacent quads). Topographic Map Series, 1:24,000, 7.5 Minute Series. Washington, D.C.: United States Government Printing Office, 1982.

64. See Notes 5-18 for the location of the Indian villages. The roads depicted on Figure 5 in Louisiana and the townships are adapted from Note 19. For the location of the roads in Texas, see Note 60.5. For the calculation of Terán's Line, see Note 39. 